\title{
Correlates of Effective Instructional Supervision in Bayelsa State Secondary Schools
}

\author{
Omemu, Felix ${ }^{1, *}$ \\ ${ }^{1}$ Department of Educational Foundations, Faculty of Education, Niger Delta University, Wilberforce Island, \\ Amassoma, Bayelsa State, Nigeria \\ *Correspondence: Department of Educational Foundations, Faculty of Education, Niger Delta University, \\ Wilberforce Island, Amassoma, Bayelsa State, Nigeria. Tel: 234-803-3056-943. E-mail: anniebella143@yahoo.com
}

Received: July 10, 2017

Accepted: July 27, 2017 Online Published: August 14, 2017

doi:10.5430/wje.v7n4p40

URL: https://doi.org/10.5430/wje.v7n4p40

\begin{abstract}
The purpose of this study is to examine the correlates of effective instructional supervision in secondary schools in Bayelsa State. A critical examination of all the policies and personnel put in place by the government to achieve the aim of supervision of instruction in secondary school in Bayelsa State were elucidated. The study involved empirical design with the stratified population of fifteen (15) secondary schools, comprising three hundred (300) teachers and sixty (60) supervisors (Principals) randomly selected from three geo-political zones (Sub divided into: Riverine, Upland and Midland). The research instrument used for the study was rating scale consisting of five (3) research questions. The analysis involved the use of mean and standard deviation, why the hypotheses were analyzed using Z-test at 0.05 level of significance.

The results of the analysis indicated that: demography, status/personality and perceptions are not a major factor that influences supervision of instruction in schools, but quality and number of teachers, incentives and motivation, quality and number of supervisors, and school location are the correlates factors that influence supervision of instruction in schools. Conclusively, the researcher recommends that supervision is very important for effective instruction in secondary schools and that government should provide all it takes to motivate teachers as to enhance regulation of supervision of instruction.
\end{abstract}

Keywords: supervision; instruction; instructional supervision

\section{Introduction}

Supervision is an important function for school administration. It is located at different levels of the superstructure that set up the schools firstly, government supervises schools by laying down the general and fiscal policies of how the school system is run. The ministry of education and other agencies are set up as well to monitor the activities of the school and teachers to ensure quality supervision. Therefore, supervision is one of the administrative tasks in any school and could be traced to the missionaries who introduced formal education to Nigeria. There had been informal forms of instructions, which involved the "handing" down of wisdoms from the old to the young, even at this level, such activities were supervised.

Today's secondary schools are more complex to the one-room neighbourhood schools of decades past. There exists nascent population explosion in our secondary schools, which makes it possible for a class to have as many as eight to ten streams of seventy to hundred students in each class despite the educational regulation policy of one teacher to at most forty student $(1: 40)$. Alsothe faculty and services in secondary schools are becoming increasingly tasked to manage, but the social expectations from the schools are becoming extremely demanding.

Instructional supervision in the modern era centres on the improvement of the teaching-learning situation to the benefits of both the teachers and learners, helps in the identification of areas of strength and weaknesses of teachers, follow-up activities that should be directed at the improvement of identified areas of teachers' weaknesses and give recognition to the teachers and create a cordial working atmosphere based on good human relations. National Open University of Nigeria observed that Supervision provides opportunities for teachers to be groomed through critical study of instructional processes and classroom interactions to carry out their teaching tasks in line with professional 
codes of conduct. If schools are not supervised adequately, it will have inimical effects on the students' output and the educational objectives may not be achieved, consequently various instructional supervisory techniques should be employed to ensure qualitative and quantitative service delivery by the teachers.

Since Instructional supervision constitutes the leverage point for instructional improvement, teacher's competence and efficiency in the educational system while an unsupervised instruction may mar the standard of education. It is therefore, suggested that principals as catalysts should facilitate the implementation of the various sets of instructional activities geared towards an effective, viable, vibrant and qualitative educational system that will improve the teaching-learning situation in the input - process - output framework without which the educational endeavours may be an exercise in futility.

Ezeocha (2000) asserted that supervisors is concerned with the determination of the ends to be attained, the design for the procedures for affecting the ends and the assessment of results for example in determining the ends to be achieved the supervisors helps in the:

$>$ Formulation of the aims of education and the objective of supervisory activities. This helps the teachers and stakeholders to be acquainted with her happenings.

$>$ Designing of procedures affecting the ends to be met through activities such as classroom visitation, individual conferences with teachers, and teachers rating (for beginning teachers) and upgrading of old-fashioned teachers. Also substitution of teachers or replacement of weak/failing ones.

$>$ Selection of good textbooks and other instructional materials for use by teachers in unit or micro teaching.

$>$ Organization of conferences and workshop for teachers.

$>$ Assisting teachers in administering test and interoperation of results and use of data preparation of manual and bulleting to highlight or update information.

$>$ Development of evaluation techniques.

$>$ Demonstration of class co-ordination.

$>$ Acting as consultants for local facilities and developing plans for reporting pupils' activities/ programmes to parents.

$>$ Preparation of annual reports, which should serve as evaluation of supervisor's work for the year and a plan for the future.

Supervision concentrates more on monitoring and harmonization of all the activities necessary for achieving the objectives set up for the school. Supervision according to Obagah (2001) is the process of bringing about improvement in instruction by working with the people who are working with pupils. He went further to say that supervision is a process of stimulating growth and means of helping teachers help themselves. It is a process of releasing energies of people in creative ways to solve individual and common problems. Nwaogu (2000), writing on the meaning of supervision, supervision is the process of bringing about improvement in instruction by working with people who work with pupils. Still on supervision, he continued the process of supervision is to facilitate learning of pupils. Adequate supervision therefore is concerned with making adequate provision for all of the conditions which are essential to effective learning through effective teaching.

Instruction is the purposeful direction of the learning process. Classroom instruction is a bilateral activity between teaching and studying. Both the teacher and students are active participants in the learning process, each with their respective responsibilities. According to Gagne' (2000), instruction means arranging the conditions of learning that are external to the learner. These conditions need to be constructed in a stage-by-stage fashion, taking due account at each stage of the just previously acquired capabilities of the learner, the requirements for retention of these capabilities and the specific situation needed for the next stage of the learning.

Instruction is aimed at changing behaviour, so it is useful to think of a unit of instruction as being built around desired behaviour that is the learning outcome.

From the above definitions, it is seen that instruction is purposeful in directing learning process. It is a vitally important classroom activity that involves both the teacher (as the instructor) and students (as learners). Therefore, it makes the need to supervise instruction more important and inevitable to achieve educational goals. 


\section{Concept of Instructional Supervision}

Wiles and Lovell (1992) defined supervision of instruction as the maximum development of the teacher into the most professionally efficient person he or she is capable of becoming. This definition therefore indicates that supervision is all about promoting leadership and teachers' growth in educational practices.

Nwaogu (2000) view supervision of instruction as a process or an activity by which an individual or a group of individuals by means of advising and stimulating interest in teachers and pupils help to improve teaching and learning situations in educational institutions. It is also the process of assisting the teacher to improve himself and his instructional abilities so as to enhance effective teaching and learning. So if instruction is not achieved there is something wrong with the supervision.

Again it can be seen from this definition that supervision is supposed to help teachers help (improve) themselves. The supervisor ensures that the teacher teaches in such a way that the child understands so that he acquires the abilities, the skills, and attitudes stated in the objectives of instruction.

Supervision of instruction is "a complex process that involves working with teachers and other educators in a collegial, collaborative relationship to enhance the quality of teaching and learning within schools and that promotes the career long development of teachers". According to Oliva and Pawlas (1999:11), "supervision of instruction is a means of offering to teachers specialized help in improving instruction". It is clear that these definitions revolve around helping teachers, facilitating and improving instructions. This obviously indicates that there are two interacting aspects of the instructional supervisory process: the supervisor and the teacher.

\section{Research Problem}

Despite several studies undertaken to solve the problem associated with the quality of instructional supervision in schools, the problem of quality instructional supervision in Bayelsa State still persists due to poor accessibility in the riverine regions, finance, quality of supervisors etc. For one thing, supervision of instruction is intended to improve school performance and school failure is still the worry of most stakeholders. One therefore, wonders as to what makes effective supervision and how they relate to effective instruction resulting in the success of the school. In dealing with this, what comes into mind immediately are the school infrastructure, the quality of the teacher, the motivation of the supervisors, the quality of the supervisors and the location of the school. These may make a difference and may be related to effective supervision and also school performance.

\section{Purpose of the Study}

The purpose of this study is to examine and analyze the factors influencing effective instructional supervision in secondary schools in Bayelsa state.

Specifically, the study is aimed at determining the:

1) Correlates of effective instructional supervision in secondary schools.

2) Importance of incentive and motivation as compared to the amount of output of the supervisors.

3) Efficiency and effectiveness of supervision in secondary schools.

4) Supervisor's attitude to various locations of schools, considering distance from homes and offices.

5) Levels of exposure, quality and numbers of supervisors and teachers have on supervision.

\section{Research Questions}

1) Does incentives and adequate remuneration of staff a correlate to effective instructional supervision in secondary schools?

2) Do the quality and quantity of supervisors/teachers correlate to effective instructional supervision in schools?

3) Is school location a correlate to effective instructional supervision in secondary schools?

\section{Research Hypothesis}

1) There is no significant relationship incentives and adequate remuneration of staff to effective instructional supervision in secondary school. 
2) There is no significant relationship between quality and quantity of supervisors/teachers to effective instructional supervision in secondary school.

3) There is no significant relationship between school location and effective instructional supervision in secondary school.

\section{Methodology}

A descriptive research survey design was used in the study. The population of the study comprised two hundred and forty three(243) secondary schools in Riverine, Upland and Midland of Bayelsa state. A total of 360 respondents consisting of 60 school principals and 300 teachers formed the sample of the study. Self designed instruments tagged Correlates of Effective Instructional Supervision in Secondary Schools (CEISISS) was used to collect data for the study. The data collected were analyzed using mean and standard deviation for the research questions, and Z- test was used for analyzing the hypothesis. The hypothesis formulated was tested at 0.05 level of significance.

For decision making, 2.50 would be used as the criterion mean, any item that attained a response mean score of 2.50 and above was accepted otherwise it would not be accepted. The data would be collated item by item and analyzed by merging of research questions and hypothesis table together.

\section{Results}

Data were analysed and results were presented according to the research questions.

\subsection{Research Question One}

Does incentives and adequate remuneration of staff a correlate of effective instructional supervision in secondary school

Table 1. Teachers' Response on Incentives and Adequate Remuneration of Staff

\begin{tabular}{|c|c|c|c|c|c|c|c|c|}
\hline \multirow{3}{*}{$\begin{array}{l}\text { Extent of Provision of Incentives } \\
\text { and Adequate Remuneration of } \\
\text { Staff }\end{array}$} & \multicolumn{4}{|c|}{ Response } & \multirow[t]{3}{*}{ Total } & \multirow{3}{*}{$\begin{array}{r}\text { Mean } \\
\qquad \bar{X}\end{array}$} & \multirow{3}{*}{$\begin{array}{l}\text { Std. Dev. } \\
\text { r. }\end{array}$} & \multirow[t]{3}{*}{ Decision } \\
\hline & SA & A & $\mathrm{D}$ & SD & & & & \\
\hline & 4 & 3 & 2 & 1 & & & & \\
\hline Salaries Paid as at when due & 125 & 110 & 60 & 5 & 300 & 3.18 & 0.81 & Accepted \\
\hline Incentives given for extra effort & - & _ & 281 & 19 & 300 & 1.94 & 0.24 & Rejected \\
\hline $\begin{array}{l}\text { Provision of materials needed for } \\
\text { supervision }\end{array}$ & 170 & 120 & 10 & . & 300 & 3.53 & 0.56 & Accepted \\
\hline $\begin{array}{l}\text { Motivation of Staff } \\
\text { through allowances etc }\end{array}$ & - & 45 & 251 & 4 & 300 & 2.14 & 0.38 & Rejected \\
\hline Salary increment as at when due & - & 45 & 253 & 2 & 300 & 2.05 & 0.30 & Rejected \\
\hline
\end{tabular}

Standard reference mean $\bar{X}=2.50$

Table 1 shows that mean ratings of 3.18 and 3.53 respectively which are greater than the standard reference mean of 2.50 indicates that teachers were of the view that Salaries of Staff and Provision of Materials needed for supervision contributes to effective instructional supervision in secondary schools. However, mean rating (1.94), (2.14) and (2.05) respectively which are less than 2.50 indicates that the teachers were of the view that incentives, motivation and salary increment do not necessarily contribute to effective instructional supervision in secondary schools. The values of standard deviations obtained as shown in the table above indicates that teachers were homogeneous in their response.

Table 2 shows that mean ratings of 3.05 and 3.40 respectively which are greater than the standard reference mean of 2.50 indicates that supervisors were of the view that salaries and provision of materials needed contributes to effective instructional supervision in secondary schools. However, mean rating (2.02), (2.0) and (1.95) respectively which are less than 2.50 indicates that the supervisors were of the view that incentives, motivation and salary increment do not necessarily contribute to effective instructional supervision. The values of standard deviations computed as shown in the table above indicates that the supervisors were homogeneous in their responses. 
Table 2. Supervisors' Response on Incentives and Adequate Remuneration of Staff

\begin{tabular}{|c|c|c|c|c|c|c|c|c|}
\hline \multirow{3}{*}{$\begin{array}{l}\text { Extent of Provision of Incentives } \\
\text { and Adequate Remuneration of Staff }\end{array}$} & \multicolumn{4}{|c|}{ Response } & \multirow[t]{3}{*}{ Total } & \multirow{3}{*}{$\begin{array}{r}\text { Mean } \\
\bar{X}\end{array}$} & \multirow{3}{*}{$\begin{array}{c}\text { Std. Dev. } \\
\text { r. }\end{array}$} & \multirow[t]{3}{*}{ Decision } \\
\hline & SA & $\mathrm{A}$ & $\mathrm{D}$ & SD & & & & \\
\hline & 4 & 3 & 2 & 1 & & & & \\
\hline Salaries Paid as at when due & 10 & 43 & 7 & - & 60 & 3.05 & 0.53 & Accepted \\
\hline Incentives given for extra effort & - & 8 & 45 & 7 & 60 & 2.02 & 0.50 & Rejected \\
\hline $\begin{array}{l}\text { Provision of materials needed for } \\
\text { supervision }\end{array}$ & 32 & 20 & 8 & - & 60 & 3.40 & 0.71 & Accepted \\
\hline $\begin{array}{l}\text { Motivation of Staff } \\
\text { through allowances etc }\end{array}$ & - & 4 & 52 & 4 & 60 & 2.0 & 0.37 & Rejected \\
\hline Salary increment as at when due & - & 8 & 50 & 2 & 60 & 1.95 & 0.33 & Rejected \\
\hline
\end{tabular}

Standard reference mean $\bar{X}=2.50$

\subsection{Research Question Two}

Does the quality and quantity of supervisors/teachers correlate to effective instructional supervision in schools.

Table 3. Teachers' Response on Extent of Quality and Quantity of Supervisors'/Teachers'to Effective Instructional Supervision

\begin{tabular}{|c|c|c|c|c|c|c|c|c|}
\hline \multirow{3}{*}{$\begin{array}{l}\text { Extent of Contribution of Quality and } \\
\text { Quantity of Supervisors/Teachers to } \\
\text { effective Instructional Supervision }\end{array}$} & \multicolumn{4}{|c|}{ Response } & \multirow[t]{3}{*}{ Total } & \multirow{3}{*}{$\begin{array}{l}\text { Mean } \\
\bar{X}\end{array}$} & \multirow[t]{2}{*}{ Std. Dev. } & \multirow[t]{3}{*}{ Decision } \\
\hline & SA & A & $\mathrm{D}$ & SD & & & & \\
\hline & 4 & 3 & 2 & 1 & & & $\gamma$. & \\
\hline $\begin{array}{l}\text { Selection and recruitment of qualified } \\
\text { supervisors and teachers }\end{array}$ & 80 & 170 & 42 & 8 & 300 & 3.07 & 0.71 & Accepted \\
\hline $\begin{array}{l}\text { Provision of materials needed for } \\
\text { supervision }\end{array}$ & 64 & 196 & 40 & - & 300 & 3.08 & 0.58 & Accepted \\
\hline $\begin{array}{l}\text { Regular in-service training of supervisors } \\
\text { and teachers }\end{array}$ & 70 & 202 & 28 & - & 300 & 3.14 & 0.55 & Accepted \\
\hline $\begin{array}{l}\text { Availability of enough qualified } \\
\text { supervisors }\end{array}$ & 54 & 192 & 48 & 6 & 300 & 2.98 & 0.65 & Accepted \\
\hline $\begin{array}{l}\text { Employment of subject experts in } \\
\text { supervision }\end{array}$ & 56 & 197 & 43 & 4 & 300 & 2.95 & 0.63 & Accepted \\
\hline
\end{tabular}

Standard reference mean $\bar{X}=2.50$

Table 3 revealed that all the mean ratings obtained for the attributes of quality and quantity of supervisors and teachers measured, were greater than the standard reference mean of 2.50. This indicates that the teachers were of the view that attributes of supervisors/teachers such as: selection and recruitment of qualified supervisors/teachers (3.07), provision of materials needed for supervision (3.08), regular in-service training (3.14), availability of enough qualified supervisors (2.98) and employment of subject experts in supervision (2.95) contributes to effective instructional supervision in secondary schools. The values of standard deviation obtained indicate that the teachers were homogeneous in their responses.

Table 4 shows that all the mean ratings obtained for the various attribute of enough qualified supervisors were greater than the standard reference mean of 2.50 , which affirmed that the supervisors were of the view; selection and recruitment of qualified supervisors (2.93), provision of materials needed for supervision (3.02), regular in-service training of supervisors (2.83), availability of enough qualified supervisors (3.03) and employment of subject experts in supervision (3.07) contributes to effective instructional supervision in secondary schools. The values of standard deviation obtained as shown in the table indicates that the supervisors were homogeneous in their responses. 
Table 4. Supervisors' Response on Extent of Quality and Quantity of Supervisors'/Teachers' to Effective Instructional Supervision

\begin{tabular}{|c|c|c|c|c|c|c|c|c|}
\hline \multirow{3}{*}{$\begin{array}{l}\text { Extent of Contribution of Quality and } \\
\text { Quantity of Supervisors to effective } \\
\text { Instructional Supervision }\end{array}$} & \multicolumn{4}{|c|}{ Response } & \multirow[t]{3}{*}{ Total } & \multirow{3}{*}{$\begin{array}{r}\text { Mean } \\
\bar{X}\end{array}$} & \multirow{3}{*}{$\begin{array}{c}\text { Std. Dev. } \\
\text { } .\end{array}$} & \multirow[t]{3}{*}{ Decision } \\
\hline & SA & A & $\mathrm{D}$ & SD & & & & \\
\hline & 4 & 3 & 2 & 1 & & & & \\
\hline $\begin{array}{l}\text { Selection and recruitment of qualified } \\
\text { supervisors }\end{array}$ & 8 & 42 & 8 & 2 & 60 & 2.93 & 0.63 & Accepted \\
\hline $\begin{array}{l}\text { Provision of materials needed for } \\
\text { supervision }\end{array}$ & 10 & 41 & 9 & - & 60 & 3.02 & 0.56 & Accepted \\
\hline $\begin{array}{l}\text { Regular in-service training of } \\
\text { supervisors }\end{array}$ & 6 & 38 & 16 & - & 60 & 2.83 & 0.58 & Accepted \\
\hline $\begin{array}{l}\text { Availability of enough qualified } \\
\text { supervisors }\end{array}$ & 12 & 38 & 10 & - & 60 & 3.03 & 0.60 & Accepted \\
\hline $\begin{array}{l}\text { Employment of subject experts in } \\
\text { supervision }\end{array}$ & 8 & 40 & 12 & - & 60 & 3.07 & 0.63 & Accepted \\
\hline
\end{tabular}

Standard reference mean $\bar{X}=2.50$

\subsection{Research Question Three}

Is school location a correlate to effective instructional supervision in secondary schools.

Table 5. Teachers' Response on School Location as a Correlate to Effective Instructional Supervision in Secondary Schools

\begin{tabular}{|c|c|c|c|c|c|c|c|c|}
\hline \multirow{3}{*}{$\begin{array}{l}\text { Extent of Contribution of School } \\
\text { location as a correlate to effective } \\
\text { Instructional Supervision }\end{array}$} & \multicolumn{4}{|c|}{ Response } & \multirow[t]{3}{*}{ Total } & \multirow{3}{*}{$\begin{array}{l}\text { Mean } \\
\qquad \bar{X}\end{array}$} & \multirow{3}{*}{$\begin{array}{l}\text { Std. Dev. } \\
\\
\text { } .\end{array}$} & \multirow[t]{3}{*}{ Decision } \\
\hline & SA & A & $\mathrm{D}$ & SD & & & & \\
\hline & 4 & 3 & 2 & 1 & & & & \\
\hline $\begin{array}{l}\text { School located in Riverine areas with } \\
\text { difficult terrain }\end{array}$ & 10 & 52 & 80 & 58 & 300 & 1.38 & 0.90 & Rejected \\
\hline Schools located along bad roads & 8 & 42 & 208 & 42 & 300 & 2.05 & 0.62 & Rejected \\
\hline $\begin{array}{l}\text { Schools located in distant rural areas } \\
\text { with lack of access roads. }\end{array}$ & 5 & 64 & 196 & 35 & 300 & 2.13 & 0.62 & Rejected \\
\hline $\begin{array}{l}\text { Schools located in rural areas with } \\
\text { good access roads. }\end{array}$ & 68 & 166 & 58 & 8 & 300 & 2.98 & 0.72 & Accepted \\
\hline $\begin{array}{l}\text { Schools located in urban areas with } \\
\text { good access roads. }\end{array}$ & 90 & 145 & 60 & 5 & 300 & 2.95 & 0.65 & Accepted \\
\hline
\end{tabular}

Standard reference mean $\bar{X}=2.50$

Table 5 reveals that mean ratings of $1.38,2.05$ and 2.13 respectively which are less than the standard reference mean of 2.50 indicates that the teachers were of the view that attributes of school location such as school located in riverine areas with difficult terrain (1.38), schools located along bad roads (2.05) and schools located in distant rural areas with lack of access roads (2.13) does not contribute to effective instructional supervision. However, mean rating of 2.98 and 2.95 which is greater than 2.50 indicates that the teachers were of the view that school located in rural and urban areas with good roads contributes to effective instructional supervision. The values of standard deviation obtained indicate that the teachers were homogeneous in their response.

Table 6 shows that the mean ratings of 2.27, 2.17 and 2.02 respectively which are less than the standard reference mean of 2.50 indicates that supervisors were of the view that school located in riverine areas with difficult terrain (2.27), schools located along bad roads (2.17) and schools located in distant rural areas with lack of access roads (2.02) does not contribute to effective instructional supervision. Meanwhile, the mean rating of 2.76 and 2.68 respectively indicates that schools located in urban and rural areas with good roads contribute to effective 
instructional supervision. Hence, values of standard deviation obtained indicate that the supervisors were homogeneous in their responses.

Table 6. Supervisors' Response on School Location as a Correlate to Effective Instructional Supervision in Secondary Schools

\begin{tabular}{|c|c|c|c|c|c|c|c|c|}
\hline \multirow{3}{*}{$\begin{array}{l}\text { Extent of Contribution of School } \\
\text { location as a correlate to effective } \\
\text { Instructional Supervision }\end{array}$} & \multicolumn{4}{|c|}{ Response } & \multirow[t]{3}{*}{ Total } & \multirow{3}{*}{$\begin{array}{r}\text { Mean } \\
\bar{X}\end{array}$} & \multirow{3}{*}{$\begin{array}{l}\text { Std. Dev. } \\
\text { r. }\end{array}$} & \multirow[t]{3}{*}{ Decision } \\
\hline & SA & $\mathrm{A}$ & $\mathrm{D}$ & $\mathrm{SD}$ & & & & \\
\hline & 4 & 3 & 2 & 1 & & & & \\
\hline $\begin{array}{l}\text { School located in Riverine areas } \\
\text { with difficult terrain }\end{array}$ & - & 19 & 38 & 3 & 60 & 2.27 & 0.54 & Rejected \\
\hline Schools located along bad roads & - & 14 & 42 & 4 & 60 & 2.17 & 0.52 & Rejected \\
\hline $\begin{array}{l}\text { Schools located in distant rural } \\
\text { areas with lack of access roads. }\end{array}$ & - & 8 & 45 & 7 & 60 & 2.02 & 0.50 & Rejected \\
\hline $\begin{array}{l}\text { Schools located in rural areas with } \\
\text { good access roads. }\end{array}$ & 10 & 31 & 15 & 4 & 60 & 2.76 & 0.81 & Accepted \\
\hline $\begin{array}{l}\text { Schools located in urban areas with } \\
\text { good access roads. }\end{array}$ & 5 & 35 & 15 & 5 & 60 & 2.68 & 0.75 & Accepted \\
\hline
\end{tabular}

Standard reference mean $\bar{X}=2.50$

\section{Analysis of Research Hypotheses}

\subsection{Research Hypothesis One}

There is no significant relationship in the mean ratings of teachers and supervisors on the contribution of incentives and adequate remuneration of staff to effective instructional supervision in secondary schools.

Table 1 shows that the null hypothesis on Z-test of relationship in the mean ratings of teachers and supervisors on the contribution of incentives and adequate remuneration of staff to effective instructional supervision was rejected at 0.05 level of significance, where the degrees of freedom (358) is at infinity $(\alpha)$.

Hence, there is a significant relationship in the mean ratings of teachers and supervisors on the contribution of incentive and adequate remuneration of staff to effective instructional supervision. However, recall that the mean rating of teachers is 3.28 , while that of supervisors is 2.96 . The two mean rating are greater than 2.50 , which mean that both teachers and supervisors agreed that provision of incentives and adequate remuneration of staff contributes to effective instructional supervision in secondary schools.

\subsection{Research Hypothesis Two}

There is no significant relationship in the mean ratings of teachers and supervisors on the contribution of quality and quantity of supervisors to effective instructional supervision in secondary schools.

Table 2 shows that the null hypothesis on Z-test of relationship in the mean ratings of teachers and supervisors on the contribution of the quality and quantity of supervisors to effective instructional supervision was accepted at 0.05 level of significance, where the degrees of freedom (358) is at infinity $(\alpha)$. Hence, there is no significant relationship in the view of teachers and supervisors on the contribution of quality and quantity of supervisors to effective instructional supervision. Recall that the mean rating of teachers is 3.07, while the mean rating of supervisors is 2.95 . The two mean are greater than 2.50 , which means that teachers and supervisors contribute to effective instructional supervision in secondary schools.

\subsection{Research Hypothesis Three}

There is no significant relationship in the mean ratings of teachers and supervisors on the contribution of school location to effective instructional supervision in secondary schools.

Table 3 shows that the null hypothesis on Z-test of relationship in the mean ratings of teachers and supervisors on the contribution of school location to effective instructional supervision in secondary schools was accepted at 0.05 level of significance where the degrees of freedom (358) is at infinity $(\alpha)$. Hence, there is no significant relationship in the views of teachers and supervisors on the contribution of school location to effective instructional supervision. It 
could be recalled that the mean rating of teachers is 2.14 , while the men rating of supervisors is 2.31 . These two mean ratings are less than the standard reference mean of 2.50 , which means that school location do no contribute significantly to effective instructional supervision in secondary schools.

\section{Discussion of Findings}

Investigation has shown that inadequacy of number of teachers, lack of incentives and motivation to supervisors, inadequacy of number of supervisors of education and inaccessible schools are the major factors identified as militating against supervision of instruction in schools. Osuji (2001), Ehiametor et al (2000), Hassan (1999), Dodd (2003) have identified these factors as militating against supervision of instruction in schools. This strongly indicates that these problems are not new but perennial to supervision of instruction in schools in Nigeria.

The implication is that the use of unqualified teachers makes the work more difficult. It is the responsibility of the supervisors to help these unqualified teachers to improve their standards through in-service training and through advisory assistance. For supervision of instruction to be effective, emphasis must be laid on the improvement of teachers in helping pupils to become independent learners. There supervised teachers should be taught to allow students to become self-dependent and self motivated with a corresponding increase in students and schools. For good quality education in Nigeria, there must be a good supply of quality teachers, who must be encouraged through in-service training and exposed to educational gadgets to improve instruction.

\section{Summary}

From the analysis of data and the discussion of the major findings obtained from the research on the research questions, the following summaries are made:

- Incentives and motivation is a major factor that influences an effective instructional supervision in schools.

- Quality and number of supervisors/teachers is seen as a major factor that influences an effective instructional supervision in schools.

- School location was also seen as another factor that influences an effective instructional supervision in schools.

\section{Conclusion}

The following conclusions are supported by the findings in this research work; the importance of supervisors' demographic variables as well as status and perception cannot be overestimated. Again, high quality and number of teachers improves supervision of instruction in schools. Incentives and motivation schemes for supervision promote instructional supervision of school. A high level quality and number of supervisors improves instructional supervision of schools.

The work of Wiles (1998), Ogunsaju (2003) and Herzberg (2001), that adequate incentives and motivation promote instructional supervision. The emphasis here is that Inspectorate of Education should not neglect the supervisors and teachers' welfare, which is important in making effective supervision of instruction. Supervision should be seen as a service rendered to both schools and teachers including their welfare, in that the supervisors and teachers are motivated to do their work properly by provision of incentive and motivation to supervisors and teachers. In other words, supervision is a service that provides the teachers the opportunity to interact with the authority, a process of give and take, which will result to improved instructional method that will equally lead to supervisor/teacher satisfaction. The supervisory function of the State Education board is a part of personnel administration geared towards improving the work attitude and effectiveness of the supervisors/teachers and should therefore be more regular, broad in outlook than is the practice now. Effective and frequent supervision will help to develop the potentials of the supervisor/teachers and this will in turn lead to improvement in instructional supervision and job satisfaction among both the supervisors and teachers.

Teachers performed better when supervision is regular; improve training and exposure of teachers to educational modern technology (gadgets) improved instruction. Regular payment of salaries makes supervisors zealous to supervise and provision of transportation allowance makes supervision of instruction worthwhile especially in the riverine areas. 


\section{Recommendations}

1) i Provision of health care benefit makes for better participation of staff in instructional supervision of schools.

ii Housing allowance ensures the comfort of staff, selection and recruitment of qualified supervisors improves supervision of instruction in schools.

2) The supervisors should have a minimum of five years of teaching experience. Professional training in school supervision, management changes innovation, educational law and general management of secondary schools should be offered in the universities.

3) Ministry of Education should meet up with the civil responsibility by updating the inspectorate/supervisory department with modern gadgets and information to their staff.

4) Frequent in-service training for supervisors and teachers of education. After recruitment, supervisors of education and teachers should be allowed and encouraged to participate frequently in State and National conference, seminars, workshops and other staff development activities that will enable them grow in their jobs and keep abreast of the times and innovations. With frequent training, supervisors and teachers will be exposed to the roles of teacher and supervisors. Moreover, in-service training also serves as incentive for staff retention.

5) Supervisors-teacher ratio should be increased to a reasonable level. More supervisors of education should be hired. When this is done, every teacher will have an opportunity of meeting with a supervisor.

6) Government should provide vehicles and boats dedicated for supervision. All unserviceable vehicles and boats should be repaired and put to use. Government should also maintain access roads to schools, and clear inland waterways of water hyacinths and abandoned boat and ships, this will improve the attitude of work efficacy.

\section{References}

Dodd, W. A. (2003). Primary school inspection in new countries. London: Oxford University Press.

Ehiametalor, E. T. (2000). Strategies in the management of education. Ibadan: Evans Brothers (Nigeria) Publishers Limited.

Ezeocha, P. A. (2000). Modem school supervision. Owerri: International Universities Press.

Gagne', R.M. (200). The conditions of learning (3rd ed.). New York: Holt, Reinhart and Winston, Inc.

Hassan, M. (1999). The role of the inspector/supervisors in educational development in Kaduna State. Unpublished master's project thesis, Ahmadu Bello University, Zaria.

Herzberg, F. N. (2001). One more time: How do you motivate employee? Harvard Business Review, 46, 53-62.

Nwaogu, J. I. (2000). A guide to effective supervision of instruction in Nigeria Schools. Enugu: Fourth Dimension Publishers Co. Ltd.

Obagah, M. O. (2001). Supervision of instruction in schools. Unpublished Master's thesis. Rivers State University of Science and Technology, Port Harcourt.

Oliva, P.F., \& Pawlas, G.E. (1999). Supervision for today's schools. New York: Wiley.

Osuji, H. G. N. (2001). The role of the inspectorate division in education for social reconstruction: Paper Presented at the NAEAP Convention held at A.I.C.E Owerri, Nigeria.

Wiles, Kimball (1998). Supervision for better. Englewood Cliffs, New Jersey: Prentice Hall, Inc.

Wiles, S.V., \& Lovell, F.B. (1998). Supervision in teacher education. Ontario: Austin Mary. 


\section{Ho1:}

Table 1 Z-Test of Relationship in the Mean Ratings of Teachers and Supervisors on the Contribution of Incentives and Adequate Remuneration of Staff to Effective Instructional Supervision

\begin{tabular}{lcclcllll}
\hline Group & $\begin{array}{c}\text { Mean } \\
\overline{\mathrm{X}}\end{array}$ & $\begin{array}{l}\text { Std. } \\
\text { Dev. }\end{array}$ & $\mathrm{N}$ & $\mathrm{df}$. & $\begin{array}{l}\text { Std. } \\
\text { Err. }\end{array}$ & Z. Cal. & Z-table $\alpha=0.05$. & Decision \\
& & & & & & & \\
\hline Teachers & 3.28 & 0.84 & 300 & 358 & 0.115 & 3.78 & 1.96 & Ho \\
Supervisors & 2.96 & 0.81 & 60 & & & & & Rejected \\
\hline
\end{tabular}

\section{Ho2:}

Table 2 Z-Test of Relationship in the Mean Ratings of Teachers and Supervisors on the Contribution of Quality and Quantity of Supervisors/Teachers' to Effective Instructional Supervision in Secondary Schools

\begin{tabular}{lclllllll}
\hline Group & Mean & $\begin{array}{l}\text { Std. } \\
\text { Dev. }\end{array}$ & $\mathrm{N}$ & df. & $\begin{array}{l}\text { Std. } \\
\text { Err. }\end{array}$ & Z. Cal. & Z-table $\alpha=0.05$. & Decision \\
& $\bar{X}$ & & & & & \\
\hline Teachers & 3.07 & 0.62 & 300 & 358 & 0.0084 & 1.43 & 1.96 & Ho \\
Supervisors & 2.95 & 0.59 & 60 & & & & & Accepted \\
\hline
\end{tabular}

\section{Ho3:}

Table 3 Z-Test of Relationship in the Mean Ratings of Teachers and Supervisors on the Contribution of School Location to Effective Instructional Supervision in Secondary Schools

\begin{tabular}{lllllllll}
\hline Group & Mean & $\begin{array}{l}\text { Std. } \\
\text { Dev. }\end{array}$ & $\mathrm{N}$ & $\mathrm{df}$. & $\begin{array}{l}\text { Std. } \\
\text { Err. }\end{array}$ & Z. Cal. & Z-table $\alpha=0.05$. & Decision \\
& $\overline{\mathrm{X}}$ & & & & & & \\
\hline Teachers & 2.14 & 0.72 & 300 & 358 & 0.087 & 1.95 & 1.96 & Ho \\
Supervisors & 2.31 & 0.59 & 60 & & & & Accepted \\
\hline
\end{tabular}

